\title{
The Implementation of a Culture of Discipline for The State Civil Apparatus (ASN) in Gorontalo Regency (A Study of the Application of Discipline Ambassador Vest)
}

\author{
$1^{\text {st }}$ Srihandayani Suprapto \\ Public Administration Department \\ Universitas Negeri Makassar \\ Makassar, Indonesia \\ nurdiansah@gmail.com
}

\author{
$2^{\text {nd }}$ Nelson Pomalingo \\ Public Administration Department \\ Universitas Negeri Makassar \\ Makassar, Indonesia \\ nurdiansah@gmail.com
}

\author{
$3^{\text {rd }}$ Haedar Akib \\ Public Administration Department \\ Universitas Negeri Makassar \\ Makassar, Indonesia \\ nurdiansah@gmail.com
}

\begin{abstract}
Discipline Ambassador Vest is one of the efforts of the Gorontalo Regency government to enforce discipline for the State Civil Apparatus (ASN). This research aims to find out the extent to which the application of the discipline ambassador vest affects the ASN in the Gorontalo Regency government. The scope of this research is the Gorontalo Regency government using qualitative method as a reference to produce descriptive data collected through in-depth interviews, observations and document analysis related to the implementation of the discipline ambassador vest. The results of this research indicate an increase in the culture of discipline of ASN in the Gorontalo Regency government, a decrease in the level of discipline violations, especially violation of working hours. In conclusion, the discipline ambassador vest is part of the government's efforts to raise awareness of the ASNs in Gorontalo Regency government towards a culture of discipline.
\end{abstract}

Keywords-Discipline, Ambassador Vest, ASN

\section{INTRODUCTION}

According to [1], work discipline is the attitudes, behaviors and actions that are in accordance with the rules of an organization both written and unwritten rules. The indicators of work discipline include goals and abilities, exemplary leaders, remuneration, justice, waskat (inherent supervision), sanctions, assertiveness and interpersonal relationship. Meanwhile, the purpose of work discipline implementation as stated by [2]-[4] is for the workers to comply with all labor regulations and policies, be able to carry out work well, utilize and maintain infrastructure and facilities as well as goods and services, act and behave in accordance with applicable norms and be able to obtain high levels of productivity. Work discipline has been identified as the most studied variable in research on organizations. The concept has been the target of most observations because work discipline and performance are interrelated and are things that can be manipulated to benefit both organizations and individuals. This is reinforced by studies conducted by several Indonesian young scholars and overseas scholars regarding work discipline. The results of research conducted by [2]-[4] concerning the relationship between teacher's work discipline and teacher performance indicate that there is a partial and simultaneous positive correlation between work discipline and teacher performance. Another study related to work discipline and employee performance improvement was carried out by [5][7] who investigated the influence of discipline on employee performance. The results of this study reveal that (1) discipline has a positive and significant influence on and contributes to improving employee performance. (2) There is a partial positive and significant influence of work discipline on employee performance. (3) The influence of discipline is measured using several indicators including compliance with the rules, effectiveness (employees complete work quickly), and corrective actions (recording all tasks assigned) [8]

Discipline is a force that develops within a worker, which causes him to adapt voluntarily to decisions, regulations, and values of work and behavior. Discipline is a person's awareness and willingness to obey all company rules and prevailing social norms. Awareness here is the attitude of a person who voluntarily obeys all regulations and is aware of his duties and responsibilities. Hence, he will obey or carry out all his duties well, not because he is forced to. Furthermore, willingness is a person's attitude, behavior, and actions that are in accordance with the regulations of an institution.

In the Gorontalo Regency government, apparatus discipline is very important and urgent because the implementation of a culture of discipline will improve their performance [9].

Discipline is a procedure that corrects or punishes subordinates for violating regulations. Discipline is a form of employee self-control regularly implemented and shows the level of sincerity of the work team within an organization. Employee discipline is a form of training that seeks to improve knowledge, attitudes and behavior of employees in order to be able to work cooperatively with other employees and improve their work performance [10].

The Gorontalo Regent's Regulation on the Work Discipline of Civil Servants in the Gorontalo Regency Government confirms that working hours for the State Civil Apparatus (ASN) are 8:00 a.m. to 4:00 p.m.. Referring to the regulation, one of the ASNs in the Gorontalo Regency government, when participating in the Leadership Education and Training Program as one of the reclassification requirements for apparatus echelon position, made a design 
to provide a deterrent effect and warning to ASNs who often lack discipline, especially related to working hours.

The design as one of the tasks in the Leadership Education and Training Program proposed to the Gorontalo Regent received positive responses from the regional government. This design as an effort to enforce discipline is a Discipline Ambassador Vest. This vest is designed in blue and has a picture of a wall clock on the back as well as the "Discipline Ambassador" written on it. This vest will be worn by ASN who are 15 minutes late or comes to office at 08.15 and worn during office hours. The implementation of this Discipline Ambassador Vest will cause: 1) a decrease in lateness, 2) the ASN who once wore the vest to avoid wearing the vest again, 3 ) shame to violate discipline.

The existence of the discipline ambassador vest is an effort to foster a culture of discipline in the government of Gorontalo regency as a form of organizational culture.

\section{RESEARCH METHOD}

This qualitative research was conducted using a case study approach. A case study approach is an approach used to investigate and understand an event or problem by collecting various kinds of information, which are then analyzed to get a solution so that the problem can be resolved. The results of this research are expected to be represented or used to describe and explain similar cases in other locations. The informants in this research were selected using deliberate sampling method; those considered to have information related to the research problems. The primary data was obtained from informants consisting of the Deputy Regent of Gorontalo Regency, the Regional Secretary, 3 Regional Secretariat Assistants, 3 Office Heads, 3 Section Heads, 3 ASNs and 3 Community Representatives. Since this research is a qualitative research, the methods of data collection used are observations, openended interviews and document analysis.

\section{RESULTS AND DISCUSSION}

\section{A. Working Hours Disclipline}

Discipline is one of the important factors in an organization because it will affect the performance of employees in the organization. The more disciplined an employee is, the higher the work performance can be achieved. Discipline is a reflection of the magnitude of a person's responsibility in carrying out the tasks assigned to him, which encourages his passion and morale. In general, good discipline takes place when employees come to the office regularly and on time and dressed well and neatly. In addition, they use materials and equipment carefully. They do work with satisfying quantity and quality and follow the work procedure determined by the organization.

Discipline is a matter of habit; every repetitive action at the same time and place; a positive habit that must be nurtured and continuously improved over time. True discipline is not formed in one or two years, but has been formed since childhood. Then, the behavior is maintained in adolescence, its meaning is lived in adulthood and the results will be obtained later.

There are at least 5 (five) essences of the Government Regulation Number 53 of 2010 which must be understood by all ASNs. (1) Absence without valid information is calculated cumulatively. If the absenteeism reaches 46 working days in a year, the apparatus will get disciplinary punishment in the form of termination. In addition, for lateness, cumulative hours count as one working day absence. (2) A direct superior who does not act/punish his staff that violates the same type of disciplinary rules. (3) The superior is fully responsible for the discipline of all his staff. (4) Staff who are absent from work without valid information for 5 (five) cumulative workdays in one year are subject to disciplinary punishment. (5) ASNs who misuse their duties are subject to severe disciplinary punishment.

Violation of the obligation to come to work and comply with the provisions of working hours is calculated cumulatively until the end of the current year (the violations committed are counted from January to December of the year concerned). As a formal legal of the State Civil Apparatus Discipline, the Government Regulation of the Republic of Indonesia Number 53 of 2010 explains that the State Civil Apparatus should comply with obligations and avoid prohibitions set forth in legislation and/or official regulations or disciplinary punishment will be given. Disciplinary violations can be in the form of speech, writing, or ASN actions that do not comply with obligations and/or violate the disciplinary provisions of ASN.

Based on the regent's regulation number 21 of 2016 on the work discipline in the Gorontalo Regency government, as stated in Chapter III article 4 and the article concerning work discipline and apparatus working hours, apparatus must comply with the working hours by coming to work on time and leaving on time. Furthermore, the working hours in the Gorontalo Regency government begins at 08.00 and ends at 16.00 .

\section{B. Disciplinary Sanctions}

Government Regulation Number 53 of 2010, Article 1 item 3 states that disciplinary violations are any words, writings, or acts of ASN that do not comply with obligations and or violate the ASN disciplinary provisions, done either within or outside working hours. The purpose of disciplinary punishment is to improve and educate the State Civil Apparatus who commit disciplinary violations. Therefore, every official who has the authority to punish, before imposing a disciplinary sentence, must first investigate the State Civil Apparatus who commit disciplinary violations. Examination will be held of the State Civil Apparatus who are suspected of committing disciplinary violations. The purpose of the examination is to make sure whether the ASN has committed a disciplinary violation. The examination also aims to find out motives behind the occurrence of these disciplinary violations. The 
examination is carried out by an authorized official or another appointed official. If the official when examining the State Civil Apparatus suspected of committing a disciplinary violation believes that, based on the results of his examination, a reasonable disciplinary sentence imposed is outside his authority, then the official must report the matter to a higher official who has the authority to punish through the hierarchical channel. The report is accompanied with examination results and other materials needed. Higher punitive authorities must pay attention to and make decisions on the report. Violation in the form of speech refers to every word spoken before or can be heard by others in meetings, lectures, discussions, on telephone, radio, television, recordings or other communication devices. Meanwhile, violation in the form of writing is a written statement of thoughts or feelings either in the form of letters or in the form of pictures, caricatures, graffiti and others similar to those. Violation in the form of act is every behavior, attitude or action. State Civil Apparatus who commit disciplinary violations will be given sanctions.

There are some kinds of sanction known in law, namely criminal sanctions, civil sanctions and administrative sanctions. In administrative law, especially in the scope of state apparatus, the administrative sanction imposed to violations of the provisions regarding marriage and divorce is disciplinary punishment. Administrative sanction in the form of disciplinary punishment is a sentence imposed on the State Civil Apparatus for violating the State Civil Apparatus Disciplinary Regulation set forth in the Government Regulation Number 53 of 2010. According to Article 7 of the Government Regulation Number 53 of 2010 concerning State Civil Apparatus Discipline Regulation, there are several levels of administrative sanction in the form of disciplinary punishment, namely: 1. Light disciplinary punishment; a. Oral Reprimand. b. Written Reprimand. c. Written Statement of Dissatisfaction. 2. Moderate disciplinary punishment: a. Periodic salary delay for a maximum of one year. b. Salary reduction by one periodic salary for a maximum of one year. c. Postponement of promotion for a maximum of one year. 3. Severe disciplinary punishment consisting of: a. demotion to a lower level for a maximum of 1 (one) year. b. position termination. c. disrespectful dismissal at his own request as the State Civil Apparatus. d. disrespectful dismissal as the State Civil Apparatus. Disciplinary punishment to the State Civil Apparatus is given by authorized officials. Officers who give the punishment are officers authorized to impose disciplinary sentences. Referring to the Government Regulation Number 9 of 2003 concerning the authority to appoint, transfer and terminate the State Civil Apparatus, officials authorized to impose disciplinary punishment are as follows: 1. Provincial Officials for Apparatus Supervision, for all Regional Civil Apparatus in their respective area, except for the following types of disciplinary punishment: a. Respectful dismissal not at his own request as a State Civil Apparatus and disrespectful dismissal as a State Civil Apparatus in the rank of Junior Administrator IV/c or above. b. Termination from echelon I structural position or other positions of which the appointment and dismissal are the president's authority. 2.
Regional Officials for Apparatus Supervision at city/regency level, for all Regional Civil Apparatus in their respective area, except for disciplinary punishment in the form of respectful dismissal not at his own request as a State Civil Apparatus and disrespectful dismissal as a State Civil Apparatus in the rank of Junior Administrator IV/c Agustian Yusuf. Sanctions for State Civil Apparatus Disciplinary Violations in the government..... 124 above, or Regional Civil Apparatus who hold positions of which the appointment and dismissal are the president's authority. In order to guarantee the effectiveness and efficiency in the implementation of the State Civil Apparatus Disciplinary Regulations, Central and Regional Civil Service Administration Officials can delegate part of the authority to impose disciplinary punishment to other officials in their respective area, except for severe disciplinary punishment in the form of respectful dismissal not at his own request as a State Civil Apparatus and disrespectful dismissal as the State Civil Apparatus in the rank of First Class Administrator IV/b or below. The delegation of authority to impose disciplinary punishment is carried out with the decree of the Civil Service Administration Official. Before imposing a disciplinary punishment, the authorized official is obliged to examine the ASN suspected of violating to find out things that incriminate and alleviate him: a. to what extent the system/work mechanism has been damaged due to the disciplinary violation; $b$. the extent to which the violation has caused harm to the State. The following are things to take into consideration: a. before imposing a disciplinary sentence, the authorized official must examine the ASN who is suspected of committing a violation. $b$. Examination must be done carefully and objectively c. Examination is done in a closed manner. Examination can be done by hearing or asking for information from others (Article 26 of Government Regulation Number 53 of 2010). The examination is carried out in order to find out whether the ASN concerned has or has not committed the disciplinary violation, to find out factors causing the person to commit the violation [11]. Meanwhile, the purposes of the examination are as follows: 1. Improving discipline and work performance. 2. Reducing the impact of a violation. 3 . Making the administration process faster. 4. Improving civil service. 5. Reducing financial leakage and waste [12]. The procedure for examining the State Civil Apparatus suspected of committing disciplinary violation is regulated in Article 24 of Regulation 53 of 2010. Article 24 explains that: 1. before an ASN is sentenced to disciplinary action, each direct superior must first examine the State Civil Apparatus suspected of committing disciplinary violations. 2. Examination as referred to in paragraph (1) is conducted in a closed manner and the results are set forth in the form of minutes of examination. 3. If according to the results of the examination, as referred to in paragraph (2), imposing disciplinary punishment on the ASN is the authority of a) the direct superior, the direct superior must impose disciplinary punishment, b) higher officials, the direct superior must report in a hierarchical manner accompanied with official report of the examination.

The examination is carried out in order to find out whether the State Civil Apparatus concerned has committed 
disciplinary violations or not and to find out factors causing him to commit disciplinary violations. Examination carried out by the competent authority must be carried out as carefully and subjectively as possible to provide the fairest possible punishment. If the State Civil Apparatus suspected of committing a disciplinary violation does not fulfill the call to be examined without a valid reason, then a second call is made. The first call can be made orally or in writing, while the second call must be made in writing. In determining the next examination date, the schedule to deliver the summons must also be considered. If the State Civil Apparatus does not fulfill the second summons, then the punitive authority imposes a disciplinary punishment based on the material available to him. This is in accordance with Article 23 paragraph (4) which reads, "If on the date of examination as referred to in paragraph (3) the State Civil Apparatus concerned is not present, then the authorized official imposes disciplinary punishment based on evidence and information without examination". Article 25 Paragraph (1) states that an examination team can be formed specifically for disciplinary violations of which threat of punishment is explained in Article 7 paragraph (3) and paragraph (4). Furthermore, Paragraph (2) states that the Examination Team as referred to in Paragraph (1) consists of direct superiors, elements of supervision, and elements of civil service or other appointed officials. Officials authorized to punish must carry out the examination. However, to speed up the examination, the official, who has the authority to punish as referred to in article 7 paragraph (1) a, b, c, and d, can form an Examination Team to examine the State Civil Apparatus suspected of committing violations, provided that the official ordered to carry out the examination is of no rank or assumes a lower position than the State Civil Apparatus examined. The instruction to carry out the examination can be given orally or in writing. For the types of disciplinary punishment as referred to in article 7 paragraph (4) b, c, d, and e, the examination must be done against the State Civil Apparatus suspected of committing a violation of which sentencing is the authority of the President. According to [13], in the framework of carrying out the examination of disciplinary violations committed by the State Civil Apparatus, there are several things to be taken into consideration. 1. Before conducting an examination, the official who is authorized to punish or other officials appointed first study carefully the reports or materials regarding disciplinary violations allegedly committed by the State Civil Apparatus concerned. 2. Basically, the examination must be carried out by an official authorized to punish. 3. Examination of the State Civil Apparatus suspected of committing disciplinary violations to impose disciplinary sentences Agustian Yusuf. Giving Sanctions for Disciplinary Violations to the State Civil Apparatus in the Government ..... 126 the authority of the President is carried out by the head of the relevant agency. 4. To expedite the examination process, the Minister, Attorney General, Secretariat Leaders of High State Institutions, Leaders of Non-Departmental Government Institutions, and Governors can order their subordinate officials to examine the State Civil Apparatus suspected of committing disciplinary violations, provided that the officials appointed has no rank or holds a lower position than the State Civil Apparatus examined. 5. The order to conduct an examination can be oral or written, one thing or another depending on the circumstances and needs. 6. The Head of the Representative of the Republic of Indonesia Overseas and the Official to whom the authority to impose disciplinary punishment is delegated must conduct an examination of the State Civil Apparatus who are suspected of disciplinary violations themselves. 7 . The examination is carried out verbally or in writing. 8. At the first level, the examination is carried out verbally and, if the results indicate that the State Civil Apparatus has committed a violation, a mild disciplinary punishment is given. 9 . Written examination is made in the form of minutes. 10. The Apparatus examined because of being suspected of committing a disciplinary violation must answer all questions posed by an authorized officer or an official ordered to conduct an examination. 11. If the apparatus examined does not want to answer the questions, then he is considered to admit the disciplinary violation alleged to him. 12. If the apparatus complicates the examination, then the examiner must report it to the official who has the authority to punish. 13. The Examiner and the Apparatus examined sign the Minutes of Examination. If the there is something in the contents of the minutes of the examination report not in accordance with what the examined Apparatus has stated, the apparatus should notify the examiner and the examiner is obliged to correct it. 14. If the apparatus examined refuses to sign the Minutes of Examination, then the Minutes of Examination are signed only by the examiner stating in it that the examined apparatus refuses to sign the Minutes of Examination and it can still be used as material to impose disciplinary punishment. 15 . The examination is carried out in a closed manner, in the sense that the examination can only be known by the authorized officials. 16. If necessary, an authorized official can request information about or regarding a disciplinary violation from another person to complete the information and guarantee objectivity. If the examination of the State Civil Apparatus has been completed, then an authorized officer must determine the imposition of disciplinary punishment. However, the official who has the authority to punish must first carefully study the report on the results of the disciplinary violation examination. Disciplinary punishment imposed must be equal to disciplinary violations committed and must be accepted with a sense of justice. One type of disciplinary sentence can be imposed on the State Civil Apparatus, which based on the results of the examination is proved to have committed several disciplinary violations. The apparatus, who has been previously subjected to disciplinary punishment, that commits the same disciplinary violation will be subject to a disciplinary punishment heavier than the last punishment imposed on him. The apparatus who are subject to disciplinary punishment can file an objection to the decision except to a light disciplinary punishment and disciplinary punishment in the form of position termination. Objection to disciplinary punishment is submitted in writing to the officer authorized to punish, namely direct superior authorized to punish through a hierarchy channel no later than fourteen days starting from 
the date of submission of the disciplinary punishment decision. Any official who accepts an objection to a disciplinary punishment must forward the objection to his superior no later than three working days after he receives the objection letter. A punitive authority who also receives an objection statement passes it on to a superior who has the authority to punish, along with records deemed necessary in connection with the disciplinary punishment determined by him, no later than 3 working days after he receives the objection letter. To facilitate the implementation of further examination, the authorized official delivers his response regarding the objection letter and minutes of the examination to the superior. Authorized superiors must study carefully the objection raised by the Apparatus subject to disciplinary punishment, as well as the reasons raised by the official authorized to punish. The superior no later than one month must make a decision regarding the objection to a disciplinary punishment. If deemed necessary, the superior of the authorized official can call and hear the statement of the official who has the authority to punish, the State Civil Apparatus sentenced to discipline, and or other people deemed necessary. This decision can strengthen or change the decision to impose disciplinary punishment established by the official who has the authority to punish and cannot be contested and must be carried out by all parties. Referring to the explanation above, the objection means the procedure adopted by a State Civil Apparatus when he feels dissatisfied with the decision made by an official authorized to punish by submitting an application for settlement to the superior of the official who has the authority to punish. After the authorized official issues a decision (beschikking), the State Civil Apparatus will of course feel aggrieved. This decision is often the beginning of a dispute between [14]. Sanctions for Discipline Violations given to the State Civil Apparatus within the Government ..... 128 The State Civil Apparatus with the State Administration Officials. State Civil Apparatus who feel aggrieved by the decision of the State Administration Agency or Official can submit their case to the State Administrative Courts. The right of the State Civil Apparatus to file a case with the State Administrative Court must first go through Administration facility.

The Gorontalo Regency Government in implementing a culture of discipline has applied the discipline enforcement vest. This vest is part of the application of discipline for ASNs in the Gorontalo Regency Government. The use of this Vest is applied when an ASN commits disciplinary violations, especially violations related to work hours. ASN who comes late must wear this vest until working hours end.
The application of this vest is expected to reduce time discipline violations. regional organization of the organization The results of the research reveal that most of the ASN had complied with the provisions regarding working hours, start work at 8:00 a.m. and end work at 16:00 even though there were a small number of ASNs who came late at each OPD (Regional Level Organization). As explained in the results of the research, the lateness of ASN was due to normative and understandable reasons, such as family matters, but they had informed it orally to direct superior in each $O P D$.

Lack of discipline and a sense of responsibility towards work is a phenomenon often found, especially in government offices, which are the main implementers of national governance and development. Adherence to the rules is not carried out consciously, sincerely and wholeheartedly leading to attitudes and behaviors that reflect lack of responsibility. Those who play a major role in the process of discipline culture development are the human resources within an agency or office. To further develop this role, the development of government apparatus is directed to improve the quality of the apparatus in order to be wiser and more dedicated to service resulting in optimal public service. Such is the existence of apparatus/civil servants as a unit in the regional governments, which has been regulated in Law Number 53 of 2010 concerning the Discipline of Civil Servants (PNS).

This enforcement of work discipline underlies the application of the Discipline Ambassador Vest conducted by the Gorontalo Regency government. This is intended to reduce disciplinary violations related to working hours.

\section{CONCLUSION}

Based on the results of the research, it can be concluded that: 1) The enforcement of discipline for ASN in the Gorontalo Regency Government has become better. This is indicated by reduced disciplinary violations committed by ASN in the Gorontalo Regency Government, 2) The application of disciplinary sanctions such as the use of a discipline ambassador vest is one of the efforts of the regional government to reduce disciplinary violations by ASN.

\section{ACKNOWLEDGEMENT}

Thanks to the Dean of the Faculty of Social Sciences who have provided financial support for this research. Furthermore, I thank the teachers and students at SMK Negeri 1 Makassar who have helped in providing data in the form of primary data and secondary data in the success of the research conducted.

\section{REFERENCES}

R. W. Renn, R. Steinbauer, dan J. Biggane, "Reconceptualizing self-defeating work behavior for management research," Hum. Resour. Manag. Rev., vol. 28, no. 2, hal. 131-143, 2018.

[2] C. M. McLeod, J. T. Holden, M. G. Hawzen, dan T. Chahardovali, "Do influxes of atypical labor make sport event workers prone to exploitation?," Sport Manag. Rev., 2018. 
[3] T. Sendlhofer dan C. M. Lernborg, "Labour rights training 2.0: The digitalisation of knowledge for workers in global supply chains," J. Clean. Prod., vol. 179, hal. 616-630, 2018.

[4] A. C. Dammert, J. de Hoop, E. Mvukiyehe, dan F. C. Rosati, "Effects of public policy on child labor: Current knowledge, gaps, and implications for program design," World Dev., vol. 110, hal. 104-123, 2018

[5] M. Curto-Grau dan G. Zudenkova, "Party discipline and government spending: Theory and evidence," J. Public Econ., vol. 164, hal. 139-152, 2018.

[6] F. Benelhadj, "Discipline and genre in academic discourse: Prepositional Phrases as a focus," J. Pragmat., 2018.

[7] B. H. Kothari et al., "A longitudinal analysis of school discipline events among youth in foster care," Child. Youth Serv. Rev., vol. 93, hal. 117-125, 2018.

[8] A. K. Sari dan H. Nurcahyanto, "Analisis Disiplin Kerja Pegawai Negeri Sipil di Badan Pendidikan dan Pelatihan Provinsi Jawa Tengah," no. 1.

[9] P. Negeri dan S. Daerah, "Kendala Dan Solusi Dalam Peningkatan Disiplin Pegawai Negeri Sipil Daerah,” 2012.

[10] A. Yusuf, "Pemberian sanksi pelanggaran disiplin aparatur sipil negara dilingkungan pemerintah daerah kabupaten sigi guna meningkatkan pelayanan publik."

[11] T. Rosenbloom dan A. Perlman, "Tendency to commit traffic violations and presence of passengers in the car," Transp. Res. Part F Traffic Psychol. Behav., vol. 39, hal. 10-18, 2016.

[12] N. Alzboun, H. Khawaldah, K. Backman, dan D. Moore, "The effect of sustainability practices on financial leakage in the hotel industry in Jordan," J. Hosp. Tour. Manag., vol. 27, hal. 18-26, 2016.

[13] J. Bédard, "The disciplinary process of the accounting profession: protecting the public or the profession? The Québec experience," J. Account. Public Policy, vol. 20, no. 4, hal. 399-437, 2001.

[14] T. Rosenbloom dan A. Perlman, "Personal resilience, discipline and safety of military drivers," Transp. Res. Part F Traffic Psychol. Behav., vol. 41, hal. 66-73, 2016. 